\title{
A fluid flow perspective on the diagenesis of Te Aute limestones
}

\author{
BRIAN D. RICKETTS* \\ VINCENT CARON \\ CAMPBELL S. NELSON \\ Department of Earth Sciences \\ University of Waikato \\ Private Bag 3105 \\ Hamilton, New Zealand \\ *Present address: Department of Geology, University of \\ Auckland, Private Bag 92 019, Auckland, New Zealand. \\ Email: b.ricketts@auckland.ac.nz
}

\begin{abstract}
Pliocene cool-water, bioclastic Te Aute limestones in East Coast Basin, New Zealand, accumulated either in shelfal shoal areas or about structurally shallow growth fold structures in the tectonically active accretionary forearc prism. Up to five stages of carbonate cementation are recognised, based on cement sequence-stratigraphic concepts, that formed on the seafloor during exposure of the limestones before burial, during burial, uplift, and deformation. Two principal fluid types are identified - topography-driven meteoric fluids and compaction-driven fluids. We have developed conceptual and quantitative models that attempt to relate the physical characteristics of fluid flow to the cement paragenesis. In particular, we have simulated the effects of uplift of the axial ranges bordering East Coast Basin in terms of the degree of penetration of a meteoric wedge into the basin. The dynamics of meteoric flow changed dramatically during uplift over the last 2 m.y. such that the modelled extent of the meteoric wedge is at least $40 \mathrm{~km}$ across the basin, and the penetration depth $1500 \mathrm{~m}$ or more corresponding with measured freshwater intersections in some oil wells. Cement-fluid relationships include: (1) true marine cements that precipitated in areas remote from shallow freshwater lenses; (2) pre-compaction cements that formed in shallow freshwater lenses beneath limestone "islands"; (3) post-compaction cements derived from compaction-driven flow during burial; (4) early upliftrelated fracture-fill cements formed during deformation of the accretionary prism and uplift of the axial ranges; and (5) late uplift-related cements associated with uplift into a shallow meteoric regime.
\end{abstract}

Keywords diagenesis; cement sequence; meteoric wedge; topography-driven flow; freshwater lens; compaction; modelling; Te Aute limestones; Pliocene-Pleistocene; New Zealand

\section{INTRODUCTION}

Diagenesis results from the dynamic interaction of rock and fluid in response to changing conditions of pressure, temperature, and chemical potential (e.g., Hutcheon 1990; Hanor 1994). The role of aqueous and nonaqueous fluids is paramount because they transfer mass and heat in response to changing hydrodynamic potential that is linked to the dynamics of basin subsidence and uplift (Bethke 1989; Harrison 1989; Bjorlykke 1994). As basins evolve, so too do the driving mechanisms for fluid flow in concert with the changing hydraulic properties of rocks, such as porosity and permeability. Diagenetic products thus provide a record of fluid evolution in terms of both composition (chemical and isotopic) and flow.

Investigation of the diagenesis of Pliocene-age Te Aute limestones in southern Hawke's Bay (Fig. 1) has demonstrated a clear link between carbonate cement paragenesis and the fluids from which the cements were precipitated or dissolved, in relation to the state of subsidence or uplift within the East Coast Basin (Caron 2002). The cool-water Te Aute limestones consist primarily of barnacle, bivalve, and bryozoan skeletal material that accumulated in a forearc basin atop an active accretionary prism (Kamp et al. 1988). Limestone deposition was not uniform across the basin, but commonly restricted to local carbonate factories that developed either on narrow shelves abutting the western margin of the forearc basin, or about intrabasin submarine ridges (Caron et al. 2004, this issue). Evidence from reflection seismic, structural, and stratigraphic studies indicates that these ridges were a manifestation of growing, thrust-cored anticlines bounding the forearc basin to the east (Pettinga 1982; Kamp et al. 1988; Field et al. 1997). The anticlines and associated faults (Fig. 2) are structurally linked to much deeper detachments in the accretionary prism (Ballance 1993; Lewis \& Pettinga 1993). Thus, the depositional environment of the skeletal deposits, and certainly the early part of their burial, were influenced significantly by differential tectonic movements, in addition to external effects such as glacio-eustasy (Kamp \& Nelson 1987)

This paper deals in the following ways with the physical environment of fluid flow that existed during diagenesis of the Te Aute limestones, with an emphasis on the Kairakau Limestone on the eastern side of the forearc basin, and the Titiokura and Te Waka Limestones along the western edge (Fig. 2, 3): (1) to develop a regional conceptual model that illustrates fluid-flow pathways and driving mechanisms in the Pliocene-Pleistocene portion of East Coast Basin as they pertain to limestone deposition, burial, and diagenesis; (2) to develop a general quantitative model of fluid flow for the Pliocene limestone units that accumulated within the forearc basin; and (3) to provide some quantitative constraints on fluid flow and the extent of the meteoric wedge during basin subsidence, and the effects on hydraulic potential during Pleistocene uplift of the Mesozoic basement axial ranges that form the western basin margin (Structural ridge in Fig. 1 inset). 


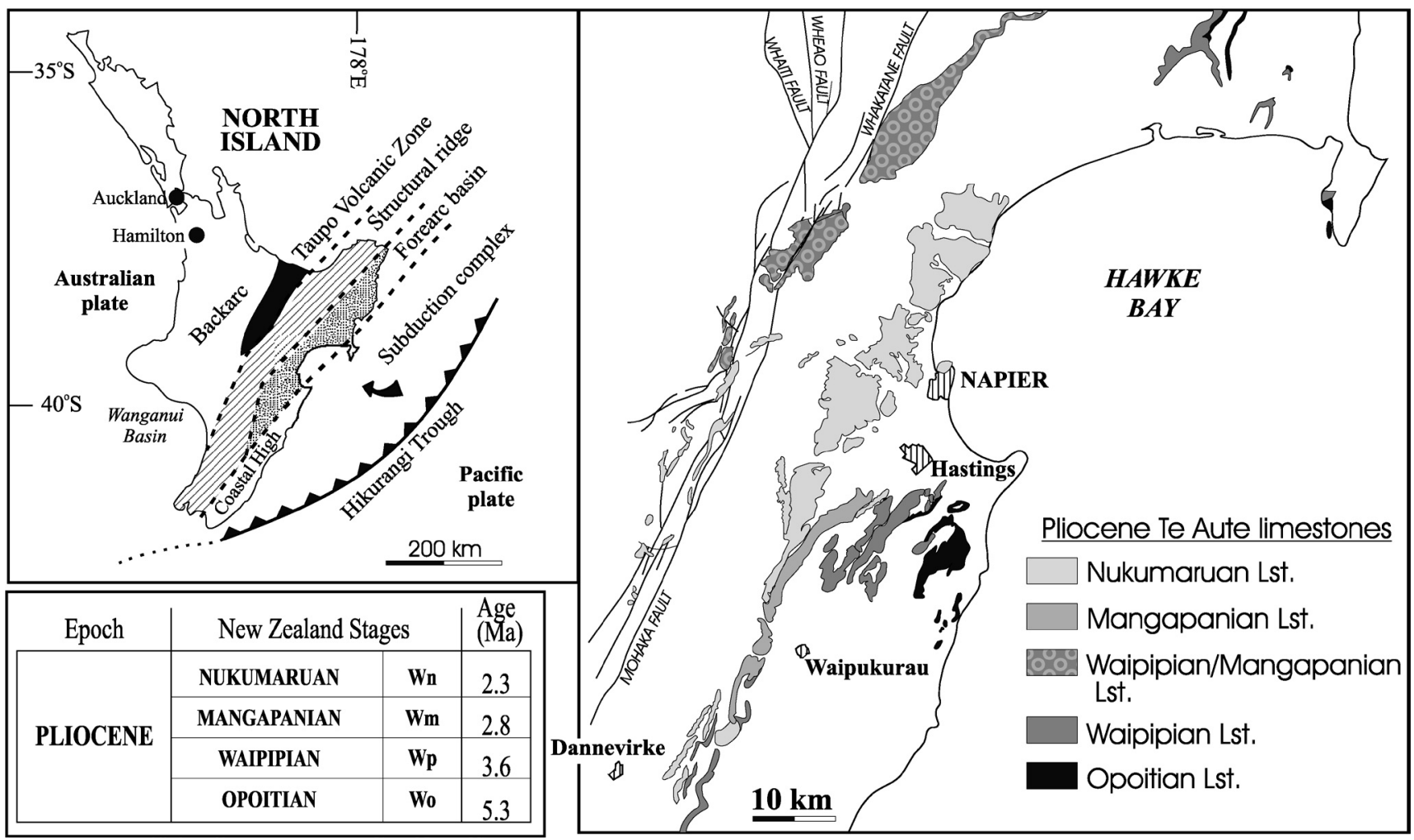

Fig. 1 Locality map and distribution of Pliocene-Pleistocene Te Aute limestones in southern Hawke's Bay, North Island. See Fig. 3 for ages of limestones.

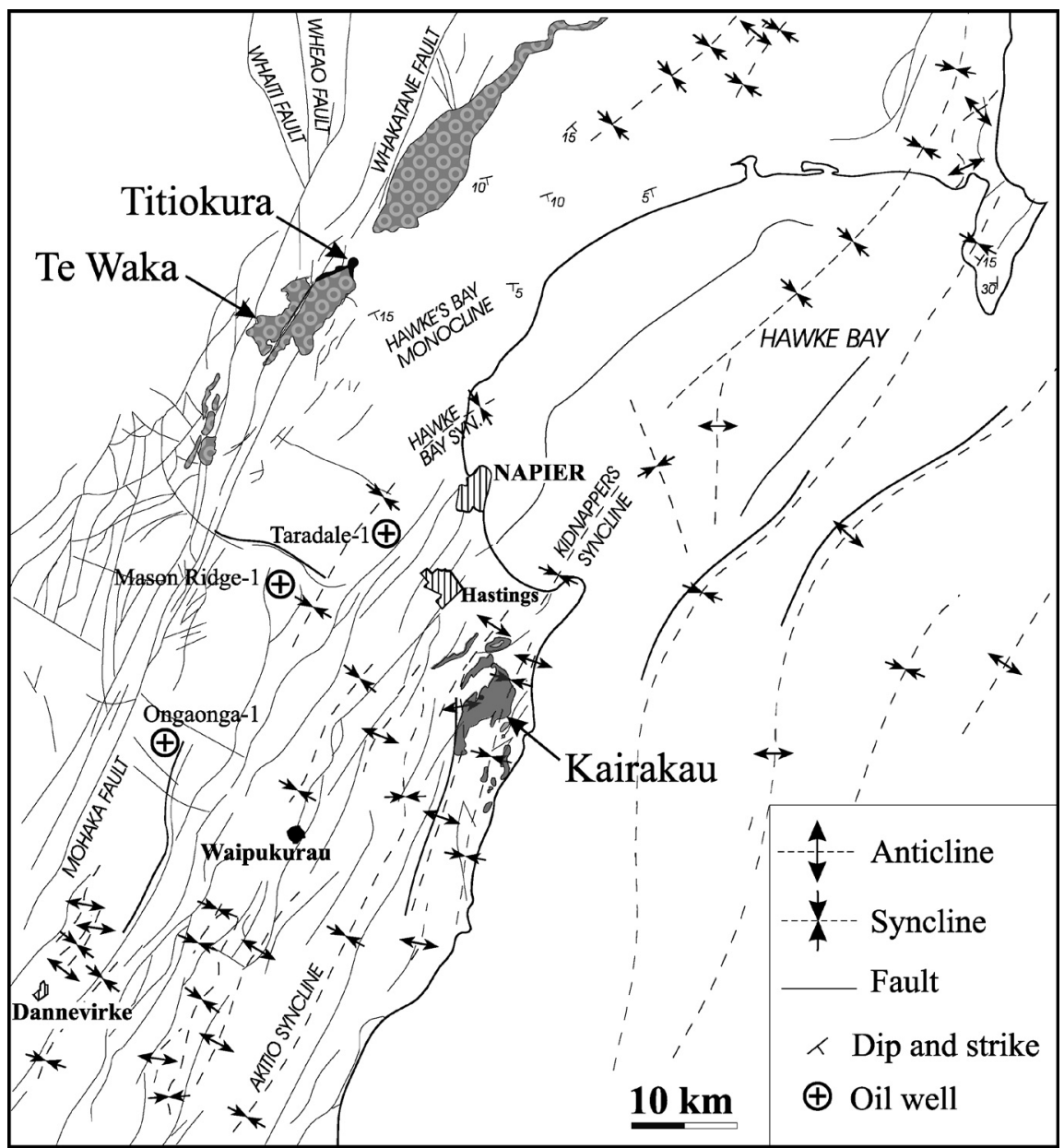

Fig. 2 Structure map of the wider Hawke's Bay region, emphasising the northeast-trending faults and fold axes (after Pettinga 1982). Outcrop areas of the Kairakau Limestone in the east, and the Titiokura and Te Waka Formations in the west are shown, as are locations for wells discussed in the text. 


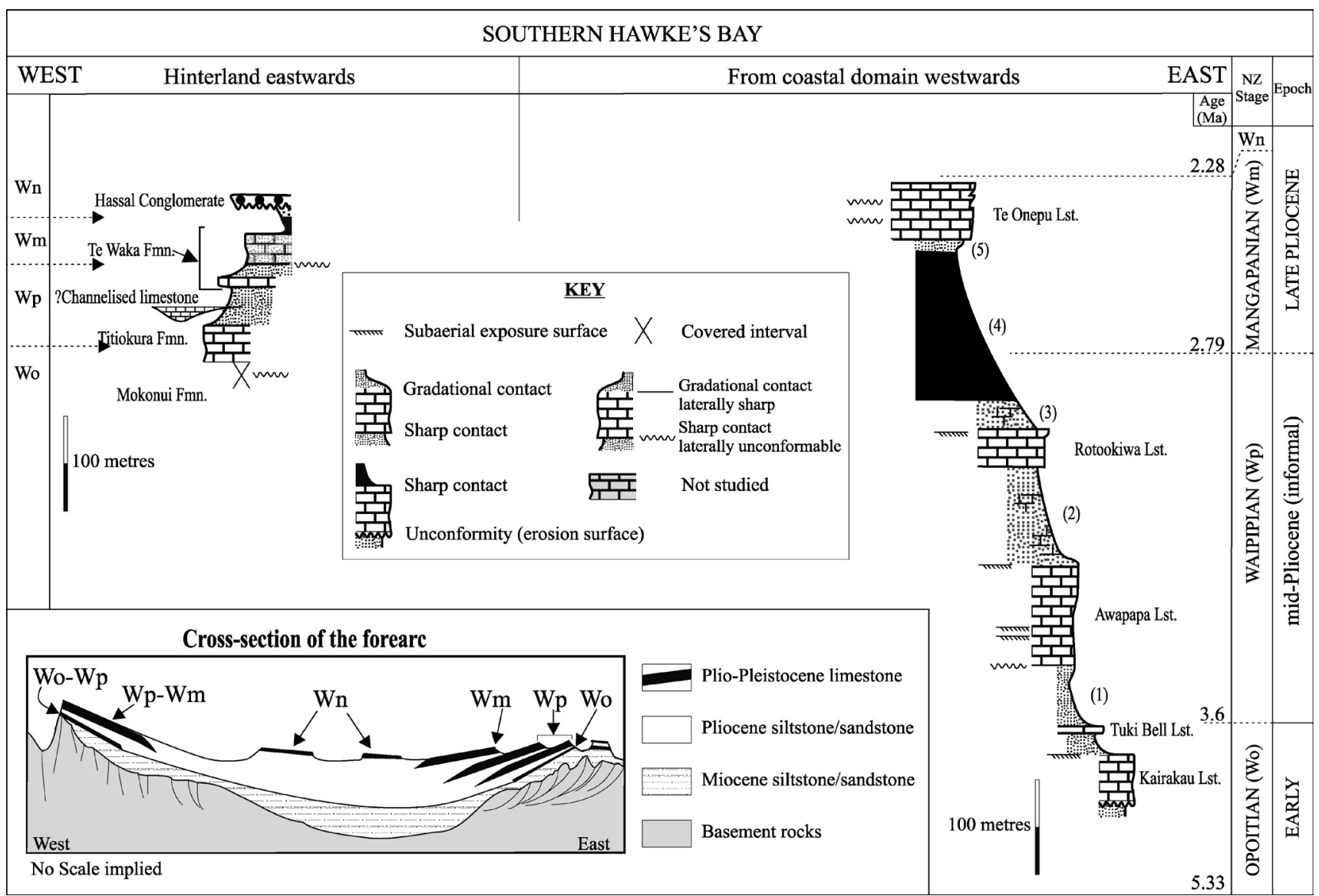

Fig. 3 Schematic age and stratigraphic relationships between the various Pliocene-Pleistocene limestones in southern Hawke's Bay, and their associated interbedded siliciclastic-dominated units: (1) Mokopeka Sandstone; (2) Pukekura Calcarenite; (3) Waikareo Calcarenite; (4) Raukawa Mudstone; (5) Argyll Sandstone (after Beu 1995).

\section{STRATIGRAPHIC FRAMEWORK OF TE AUTE LIMESTONES}

The Pliocene strata in the East Coast Basin forearc range up to $3000 \mathrm{~m}$ thick in Wairoa Syncline in northern Hawke's Bay and up to c. 2000 m offshore beneath Hawke Bay. The Te Aute limestones are typically a minor component of this succession, and are interbedded or interfinger with much thicker terrigenous shelf mudstones and sandstones that dominate the basin fill (Field et al. 1997). The Pliocene deposits unconformably overlie rocks ranging in age from Jurassic to late Miocene; onshore they are unconformably overlain by Pleistocene strata (Haywick et al. 1991; Beu 1995; Field et al. 1997). Beneath Hawke Bay, lower Pliocene strata overlie upper Miocene rocks with either angular unconformity or disconformity, depending on their position relative to syndepositionally active anticlinal ridges.

In a comprehensive study of the pectinid biostratigraphy of the limestones, Beu (1995, p. 73) demonstrated that the "Te Aute limestone is a recurrent lithofacies, repeatedly and intermittently deposited over much or all of eastern North Island at several discrete times during the Pliocene...". He therefore proposed that the name Te Aute be used only in an all-embracing lithofacies context, and not as a formal lithostratigraphic term for any particular limestone unit or group of units. The Te Aute limestones were deposited under conditions of differential uplift and subsidence, and fluctuating glacio-eustatic sea level, in shallow marine settings off shorelines and about tops of offshore highs within the East Coast Basin forearc (Kamp et al. 1988; Caron 2002). Consequently, the limestone units are highly variable in their distribution, age, thickness (a few to several tens of metres), and lateral extent. Each Te Aute limestone formation is constructed of up to 12 sedimentary sequences bounded by unconformities and displaying recurring patterns of facies stacking (Caron 2002). Schematic columns through the Pliocene deposits in the eastern and western portions of the forearc basin in southern Hawke's Bay (Fig. 3) show the stratigraphic position of the pre-Nukumaruan Kairakau, Titiokura, and Te Waka Limestones upon which we concentrate our effort.

\section{Seismic stratigraphy}

Detailed examination of reflection seismic profiles traversing offshore Hawke Bay reveals at least four seismic 3rd order sequences (i.e., 0.5-5 m.y. duration) of regional extent, based on the presence of onlap and downlap stratal patterns and erosional discordances (Fig. 4) (Ricketts et al. 2001). There are indications of higher order cycles superimposed on the 3rd order sequences but they cannot be traced beyond the profile in which they are observed and are not included in the illustrated profiles.

The sequences range in age from earliest Pliocene to the most recent sediments. SB1, the base of sequence $1(\mathrm{C} 1)$, 

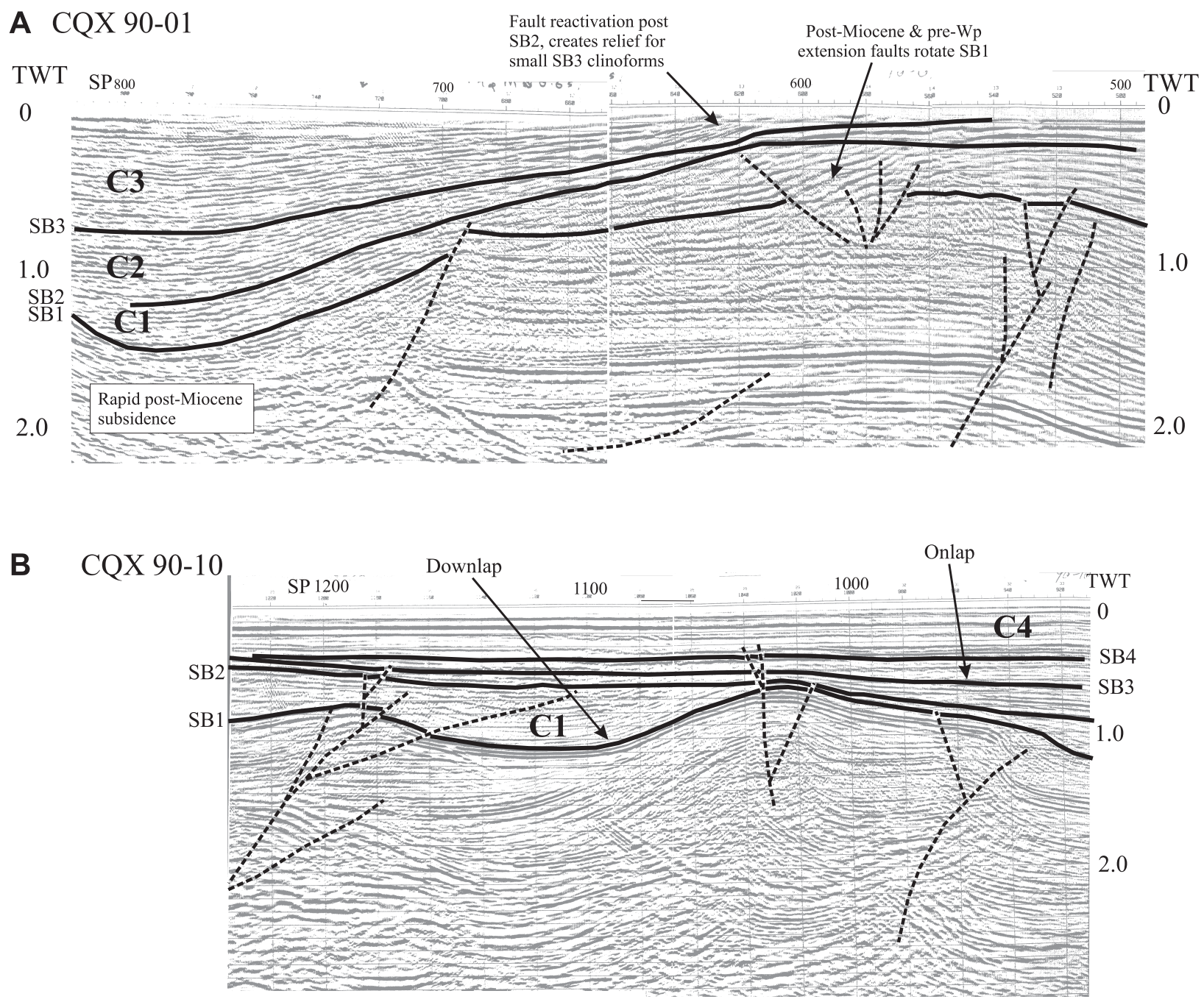

\section{CQX 90-08}
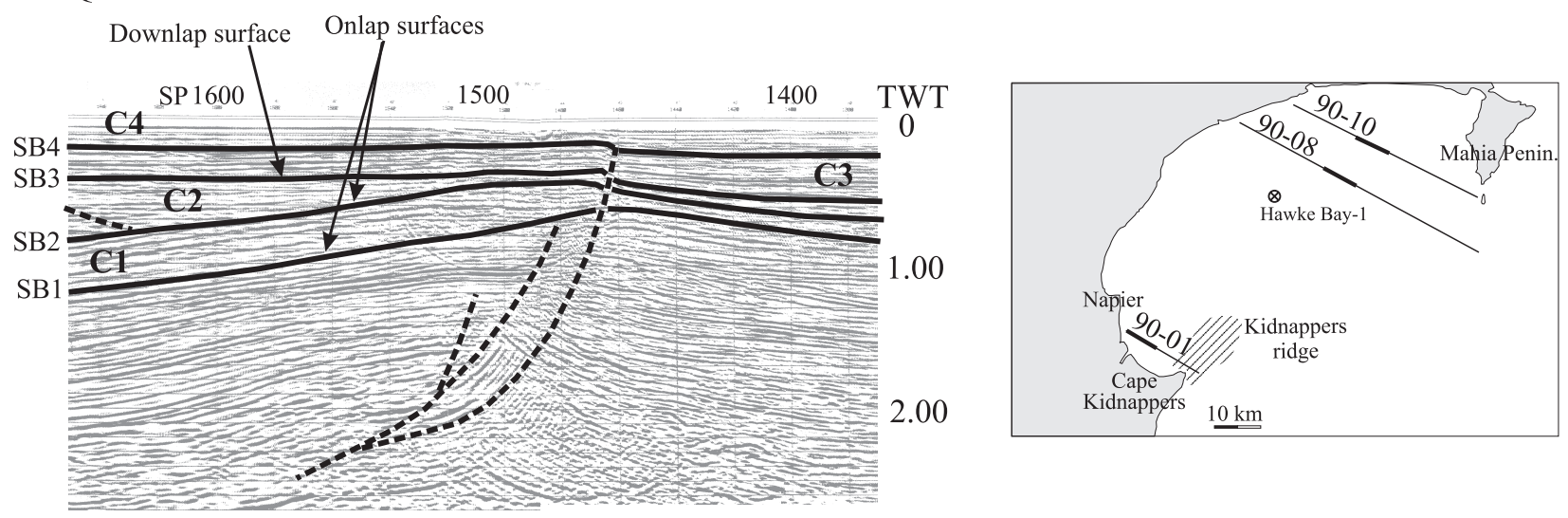

Fig. 4 Examples of seismic profiles beneath Hawke Bay (inset map) showing post-Miocene structure and seismic sequences. Important onlap and downlap surfaces are indicated. Two-way time (TWT) in seconds. $\mathrm{SP}=$ shot point. $\mathrm{C} 1$ (oldest) to $\mathrm{C} 4$ are the seismic sequences and SB1 to SB4 the sequence boundaries. SB1 corresponds to the basal Pliocene unconformity. A, Segment of CQX 90-01, west of Kidnappers Ridge. Uplift of the anticline probably began in the Miocene but continued in early Pliocene (SB1). Extension across the crest of the fold was accommodated by local block rotation before the end of the Waipipian. Significantly, extension was reactivated during sequence C2 and possibly $\mathrm{C} 3$ as evidenced by the localisation of small clinoforms prograding west of the fold crest. Sequence C3 is missing from the crest of the anticline, indicating some reactivation in the late Pliocene-Pleistocene. B, Faulted anticlines in CQX 90-10, where the basal Pliocene unconformity is folded and onlapped by younger sequences. C, Faulted anticline in CQX 90-08. Faulting and uplift were active during $\mathrm{C} 1$ and $\mathrm{C} 2$ because both sequence boundaries acted as onlap surfaces (SB1, SB2), requiring that submarine relief be present. SB3 is a downlap surface. The youngest fault strand truncates lower SB4 reflections, indicating that uplift continued throughout the Pliocene and much of the Pleistocene. 


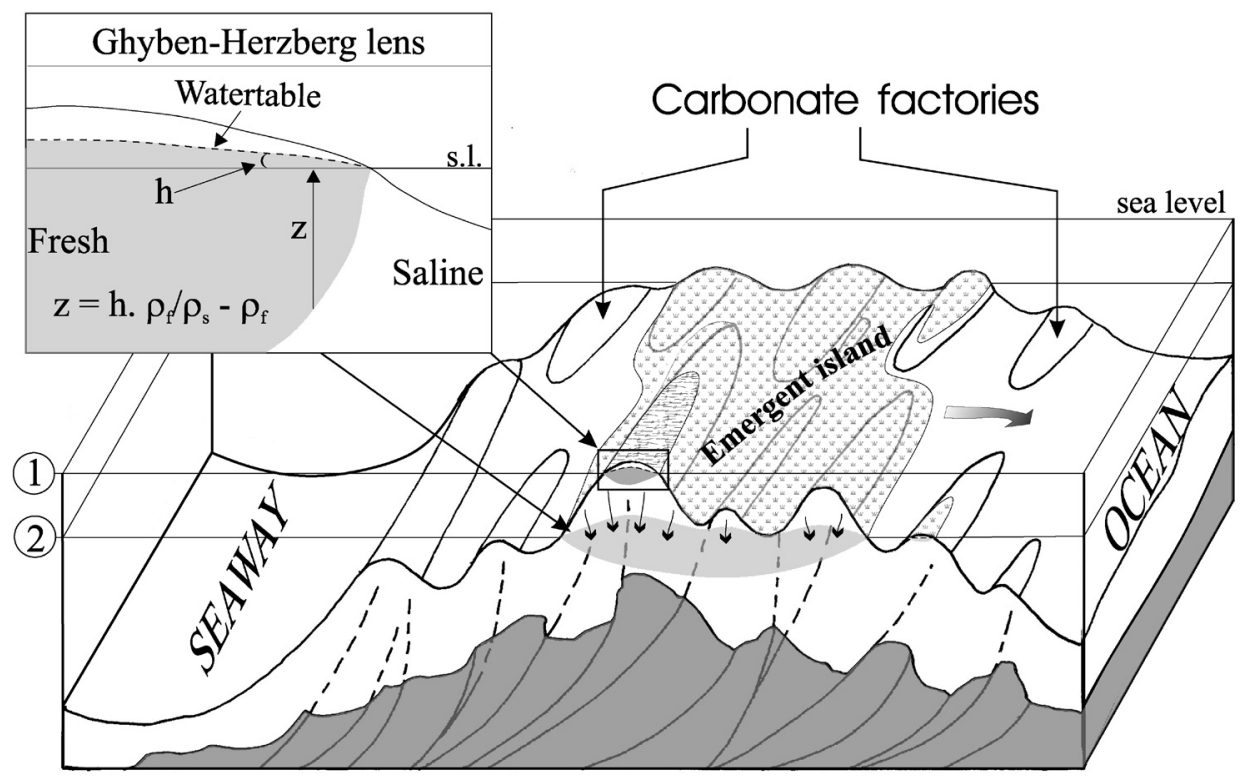

Fig. 5 Conceptual depositional model for the isolated Te Aute carbonate platform, consisting of actively growing and deforming, northeast-trending, submarine anticlinal ridges, a favoured carbonate factory for many of the Te Aute limestone occurrences. The vertical scale is greatly exaggerated. Thick single-headed arrow indicates tidal flows across depressions between subtidal banks. Thin black arrows beneath the emergent island indicate percolation of meteoric waters. Inset: The Ghyben-Herzberg parameters relating to the extent of the freshwater lens beneath the emergent Te Aute island. The size of an emergent island varies according to the amplitude of relative sea-level fall, and so does the extent of the freshwater lens. In case 1, minor sea-level fall exposes the top of some local submarine highs; as a result, the freshwater lens has a limited geographic distribution and meteoric diagenesis is likely to be minor. This case is envisaged for poorly correlatable subaerial exposure surfaces recognised within some Te Aute limestones. In case 2, major sea-level fall exposes the top of the isolated platform allowing development of an extended freshwater lens and significant precipitation of cements. This case is envisaged for the origin of more widespread meteoric cements within each Te Aute limestone prior to burial.

corresponds to the basal Pliocene unconformity. SB2, the top of sequence 1, identified in the offshore Hawke Bay-1 well as top of the Waipipian (earliest late Pliocene), is the only established time-line in the offshore area; therefore, $\mathrm{C} 1$ spans c. 1.5 m.y. The duration of the other three sequences is not established, although the youngest sequence ( $\mathrm{C} 4$ in Fig. 4) is probably late Pleistocene-Recent.

Time-depth conversions determined for the Hawke Bay-1 (Field et al. 1997) and Titihaoa-1 wells (Uruski \& Funnell 1995) are close to $1000 \mathrm{~m}$ depth per second (TWT). On this basis, the maximum thickness of the offshore Pliocene-Recent succession in Hawke Bay is c. $2000 \mathrm{~m}$. Sequence C1 has a maximum thickness of $1200 \mathrm{~m}$, implying an average sedimentation rate of c. $80 \mathrm{~cm} / \mathrm{ky}$. The basal Pliocene unconformity (sequence C1) commonly truncates Miocene strata above fault-cored anticlines, and is marked by prominent onlap and downlap architecture. The identification of widespread syn-depositional thrust and growth faults and folding within the PliocenePleistocene succession, supports earlier models that invoke tectonic control on the development, location, and large-scale geometry of the Te Aute limestone occurrences (Kamp \& Nelson 1987; Kamp et al. 1988). In several reflection seismic profiles, it is clear that faults extend into the youngest sediments of sequence C4 (e.g., CQX 90-08, Fig. 4C). However, deformation was not synchronous across the basin.

\section{DEPOSITIONAL FEATURES OF TE AUTE LIMESTONES}

On the eastern margin of the forearc basin, the Te Aute limestones accumulated as islands, banks, and bars in cool, shallow seas swept by strong tidal currents (Fig. 5) (Harmsen 1985, 1989; Kamp et al. 1988), whereas along the western edge of the basin, carbonate factories developed as coquina shoals upon a narrow landmass-attached shelf (Caron et al. 2004). The limestones consist primarily of whole and comminuted skeletal material, dominated by calcitic barnacle plates, epifaunal bivalves and bryozoans, and subordinate echinoderms, foraminifera, infaunal bivalves, brachiopods, gastropods, and calcareous red algae (Beu 1995). Crossbeds abound, including those representing tide-generated megaripples and sandwaves. Trough cross-beds in some units indicate confined or semi-confined flow in tidal channels, and giant foreset units up to $40 \mathrm{~m}$ thick are interpreted as the avalanche faces of large tidal-inlet deltas. The active sand banks and tidal delta platforms also supported lenticular biostromes composed predominantly of oysters (Crassostrea) and pectinids (Phialopecten-Towaipecten-Mesopeplum) encrusted by barnacles (Balanus).

The limestones typically are coarse grained, often coquinas, and their present porosities and permeabilities range from c. 10-40\% and 3-50 md, respectively (de Caen \& Darley 1968, 1969). Depositional porosities must have been even higher (40-60\%), as would the concomitant permeabilities. Uplift of the submarine ridges on the active eastern part of the forearc basin periodically exposed the unconsolidated skeletal carbonates as islands. Most of the islands lacked any kind of lithified rock buttress or foundation (as is commonly found on tropical carbonate islands), and therefore most islands would have had very low elevation and topographic relief - not unlike modern sand spits and barrier islands. An important consequence of this morphology is that 
Summary stacked CL sequences within limestones from the western portion of the study area
Summary stacked CL sequences within limestones from the eastern portion of the study area

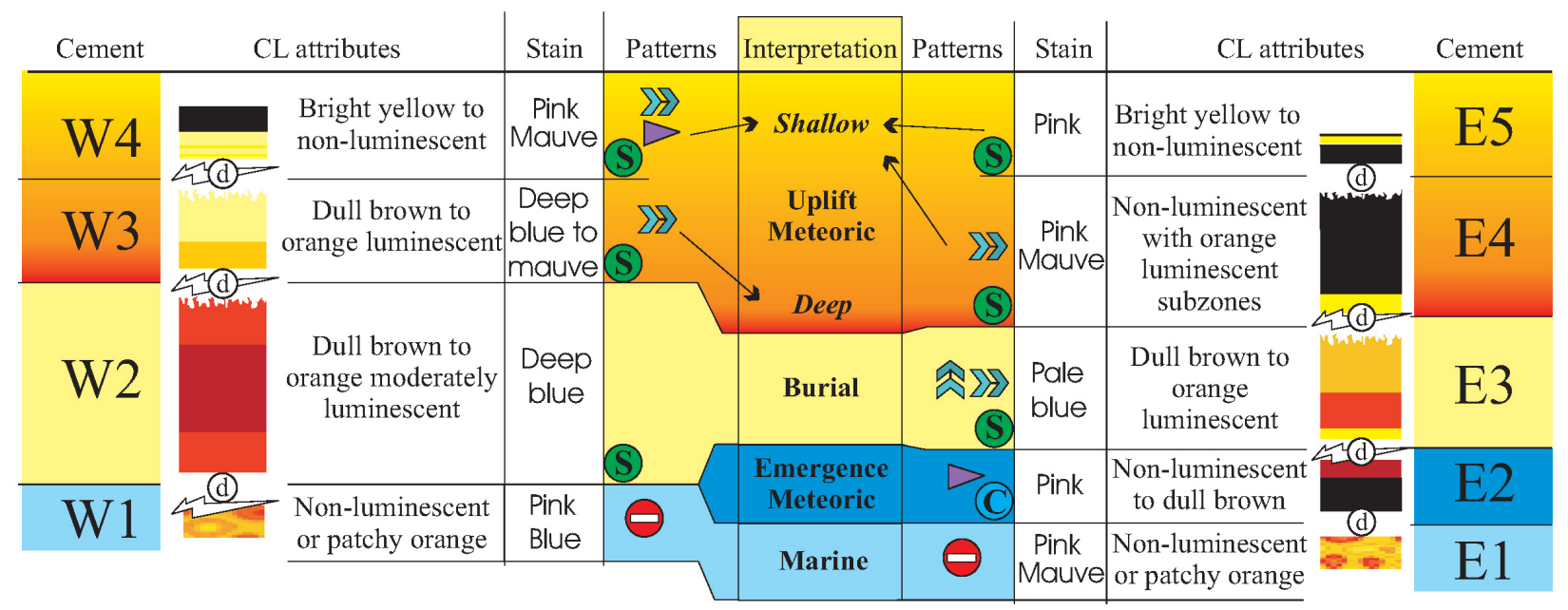

28) Lateral change of CL properties

哅 Vertical change of CL properties

- Laterally or vertically uncorrelatable cement (i.e., restricted to specific horizons)
Cement restricted to the host limestone

(S) Cement shared by at least two distinct limestone units (i.e., of different age and separated by thick siliciclastic units) (d) Dissolution

\section{Fracturing}

$\triangleright$ Lateral pinchout of cement

Chemical staining with Dickson's (1965) solution: Pink = non-ferroan

Deep blue $=$ ferroan-rich

E2 Pre-compaction (inferred) meteoric non-ferroan cement

Post-compaction telogenetic (meteoric) non-ferroan cement

$\mathrm{E} / \mathrm{W}$ Marine turbid cement

Post-compaction mesogenetic (burial) ferroan cement

Fig. 6 Summary properties of cement phases (colour coded) in the Te Aute limestones deposited on the eastern (E1-E5) and western (W1-W4) margins of the forearc basin in southern Hawke's Bay. These attributes are based on examination of over 600 thin-sections under plane polarised and cathodoluminescent light (CL; Caron 2002).

island water tables would also have had very low elevation and hydraulic gradients.

\section{TE AUTE LIMESTONE CEMENT PARAGENESIS}

Caron (2002) has undertaken a detailed petrographic and diagenetic study of the Te Aute limestones. Concepts that underpin the sequence stratigraphic analysis of sedimentary successions in the field were used to group zoned cement successions, revealed under cathodoluminescent (CL) light, into diagenetic discontinuity-bounded CL sequences. A CL sequence is a genetically related succession of cement zones bounded by correlative diagenetic discontinuities, including dissolution surfaces, renucleation surfaces, and/or fractures, which are traceable vertically over several tens of metres, and laterally over several kilometres. Full procedures, and the relationship of cement sequences to outcrop sequence stratigraphy, are discussed elsewhere (Caron \& Nelson 2003).

In the eastern sector of the study area, a distinctive succession of five CL sequences characterises the main
Te Aute limestone units, including the Kairakau, Awapapa, Rotookiwa, and Te Onepu Limestones (Caron \& Nelson 2001) (Fig. 2, 3). Here we simply name these cements E1-E5 (east, oldest to youngest). In contrast, at most localities in the western sector of the study area, Titiokura and Te Waka Limestones (Fig. 2, 3) only display up to four CL sequences, named W1-W4 (west, oldest to youngest). General properties of the various sequences are summarised in Fig. 6 and illustrated in Fig. 7. Briefly, patterns of cementation within eastern and western pre-Nukumaruan limestones differ as follows: (1) most eastern limestones bear evidence of subaerial exposure to meteoric processes for a prolonged period of time, prior to burial, allowing precipitation of non-marine cements (cement E2; Fig. 6, 7A-C), whereas within western limestones such pre-burial cements are poorly developed or absent; (2) western limestones contain thick fracture-hosted burial cements with high ferroan contents (cement W2; Fig. 6, 7D), whereas in eastern limestones fracture-hosted burial cements (cement E3; Fig. 6) are comparatively thin with low to moderate ferroan contents (Fig. 7A). 

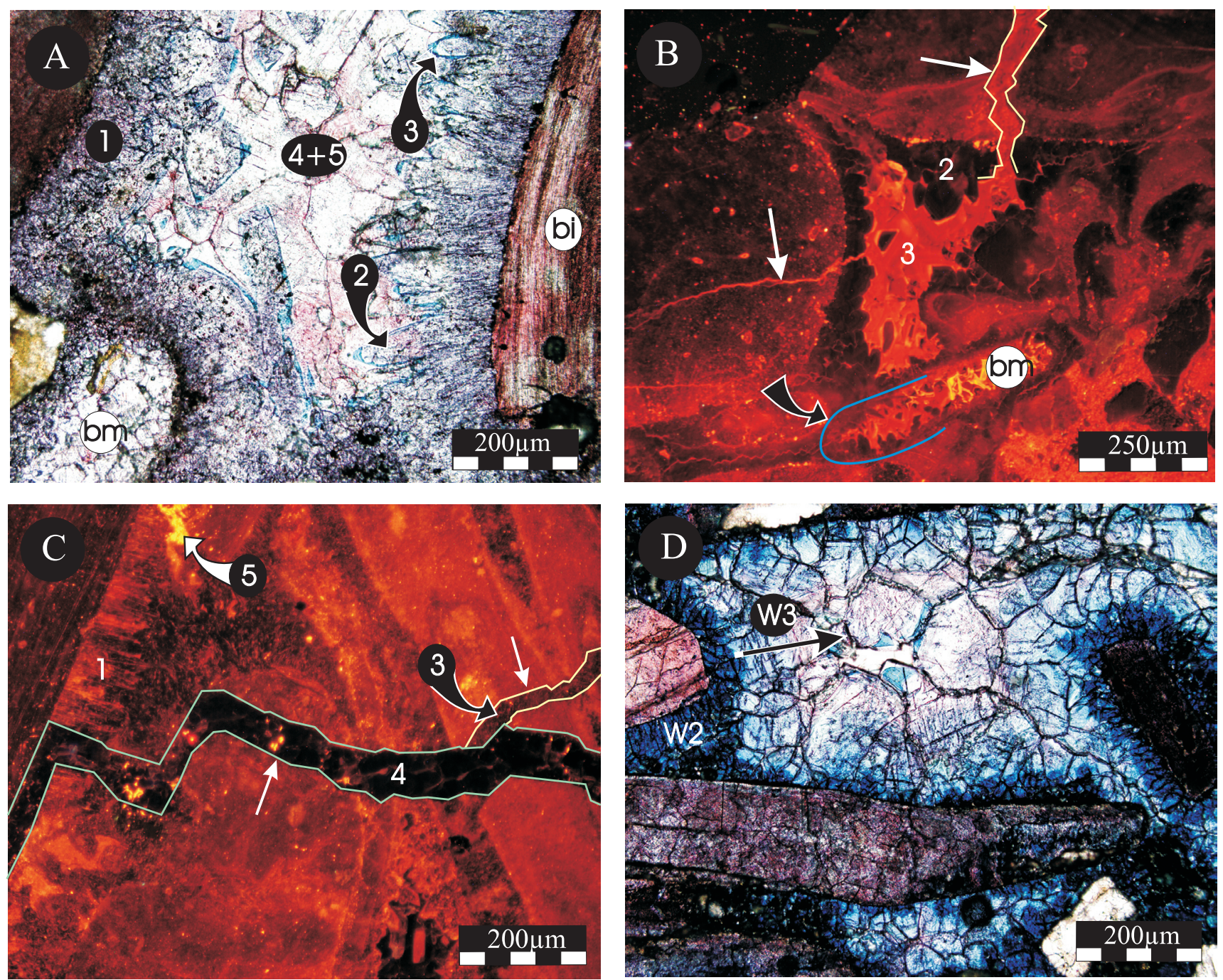

Fig. 7 Photomicrographs illustrating examples of the various cement sequences in the Te Aute Limestones (see also Fig. 6): A, Complete suite of cementation stages (1-5 equal E1-E5 in text) identified in limestones of Opoitian-Mangapanian age deposited on the eastern side of the forearc basin (see also B and C). The pre-compaction diagenetic suite consists of thick turbid seafloor cements (E1) that coat both preserved bivalve shells (bi) and moulds of former aragonitic skeletons (bm), and overgrown by non-ferroan (stains pink with Dickson's solution, 1965) meteoric scalenohedral calcite crystals (E2 arrowed). The post-compaction diagenetic suite consists of thin ferroan (stains pale blue) burial cement (E3 arrowed) followed by uplift-related meteoric non-ferroan (stains pink) mosaic spar (composite E4+5). Chemically stained sample 5.93 (Awapapa Limestone). B, Non-luminescent cement E2 is post-dated by compaction-induced fractures (white arrows) filled with orange luminescent ferroan cement E3. A dissolution surface (blue line arrowed), coincident with the inner wall of a biomould (bm), provides substrate for the non-luminescent cement generation. Cathodoluminescent light (CL): sample 4.65 (Kairakau Limestone). C, Illustration of the paragenetic relationships of pre- and post-compaction cements (E1 and E3,4,5, respectively). The youngest fracture (green line arrowed) is filled with non-luminescent cement E4, and crosscuts both the fracture (yellow line) that hosts dull luminescent cement E3 (arrowed) and pre-compaction patchy acicular seafloor cement E1. A late dissolution event produced irregular intracrystalline pores filled with brightly luminescent cement E5. Cement E2 is absent. CL: sample 4.29 (Kairakau Limestone). D, Illustration of the characteristic cementation suite identified in samples from limestones deposited on the western margin of the forearc basin. Pore-filling succession of cement phases (W2, W3) records the transition (along the arrow) from burial Fe-enriched reducing cementing fluids (cf. deep blue stain of W2 with pale blue stain of thin cement E3 in A) to more oxidising waters (pale mauve) following probable progressive uplift of the axial ranges. Chemically stained sample 15.5b (Te Waka Formation).

\section{BASIN-WIDE DIAGENETIC PROCESSES- A CONCEPTUAL MODEL}

Fluids are an essential component of sedimentary basins wherein their chemical composition and dynamics of flow evolve in concert with changes in basin subsidence, compaction, tectonism, and topography (e.g., Bethke 1989; Bjorlykke 1993; Bachu 1995). Likewise, the driving mechanisms for fluid flow also evolve. Three principal driving mechanisms are recognised in many basins, encapsulated in a simple yet compelling model for the Gulf Coast Basin, USA, presented by Galloway (1984). These mechanisms are: (1) topography-driven flow, which applies to meteoric wedges and is derived from the hinterland beyond basin margins; (2) compaction-driven flow within a subsiding basin; and (3) thermal mechanisms where flow is driven by dehydration reactions (especially in clays) or by convection.

A conceptual model for East Coast Basin (Fig. 8A-D) consists of four time-slices extending from earliest Pliocene 
A

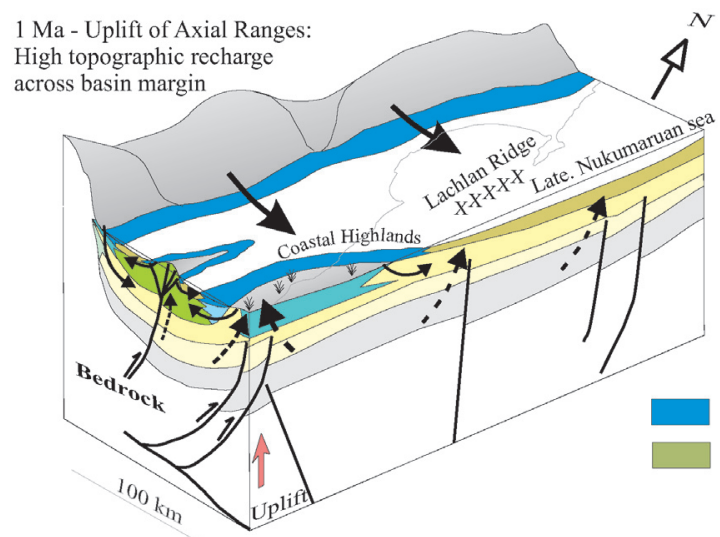

, Nukumaruan limestone

L. Nukumaruan sandstone-mudstone

B $\quad 2.5-2.8 \mathrm{Ma}$ - Early uplift of Axial Ranges: increasing topographic recharge across basin margin

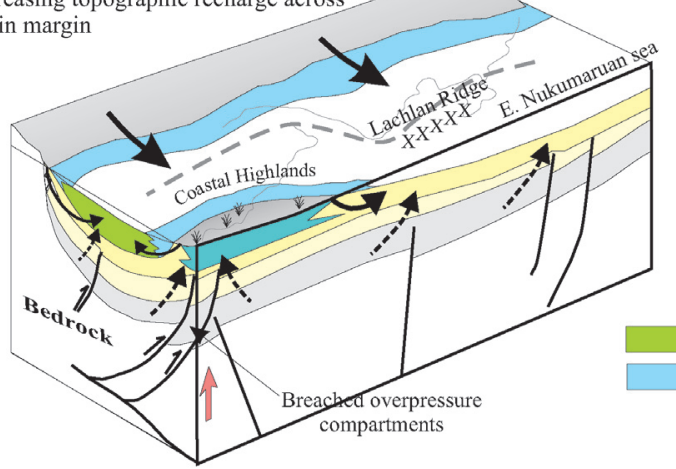

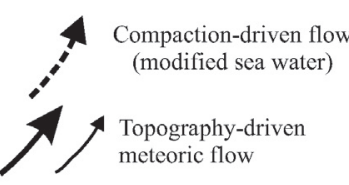

E. Nukumaruan sandstone - mudstone E. Nukumaruan limestone
Fig. 8 Conceptual models of forearc basin evolution in the Hawke's Bay region during the Pliocene-Pleistocene, highlighting potential fluid flow types and pathways at the basin-wide scale for different time periods: A, $1.0 \mathrm{Ma}$; B, 2.5-2.8 Ma; C, 3.8 Ma; D, 5.0 Ma. The coastline used for the 5.0, 3.8 , and 2.5-2.8 Ma periods is based on the palinspastic reconstruction for the early Nukumaruan (c. $2.5 \mathrm{Ma}$ ) from Beu (1995). The coastline for the $1.0 \mathrm{Ma}$ period is approximated by the modern coast.

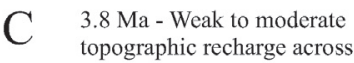
topographic rech
basin margin

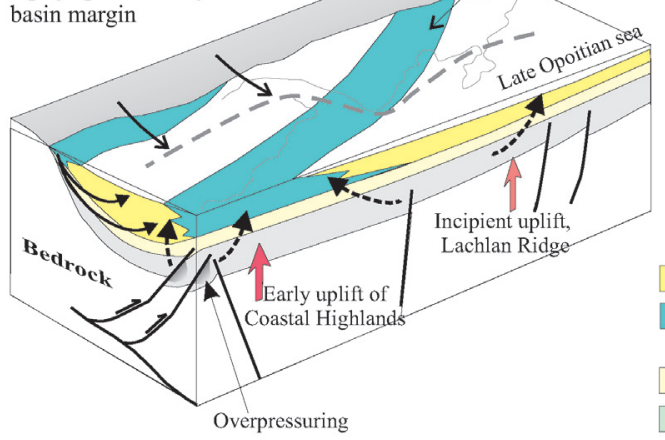

Late Opoitian sandstone - mudstone

Late Opoitian limestone

Early Opoitian sandstone - mudstone Early Opoitian limestone Paleogene - Miocene

D $5.0 \mathrm{Ma}$ - Weak to moderate topographic recharge

Pre-Tertiary bedrock

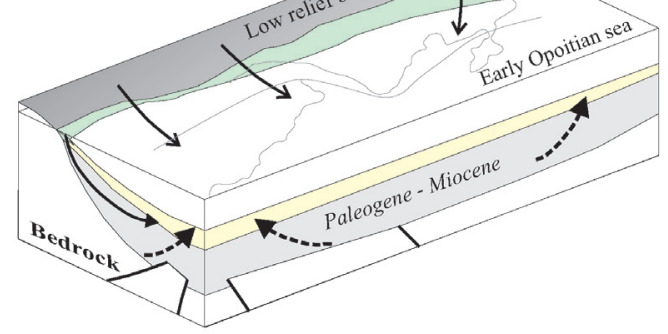


(5 Ma) to the mid Pleistocene (1 Ma). Maximum burial depths for the oldest Pliocene strata were probably at the lower end of the range 2000-3000 m, based on stratigraphic and seismic evidence, under conditions of low heat flow (30-40 $\mathrm{mW} / \mathrm{m}^{2}$; Uruski \& Funnell 1995), consistent with the thermal structure of many accretionary prisms. Claytype dehydration reactions do not take place under these burial-temperature conditions, and therefore the model only considers topography-driven and compaction-driven flow. Aqueous and hydrocarbon fluids derived from deeper levels of the accretionary prism and redistributed to structurally higher levels along active faults may also be important; these are incorporated into the conceptual model, but not the numerical models. The conceptual model attempts to illustrate the following characteristics for the late Neogene East Coast Basin:

(1) Pliocene sediment was deposited on deformed and deforming late Miocene and older rocks within the forearc basin;

(2) syn-depositional, differential uplift was an important control on the distribution and stratigraphic architecture of Pliocene-Pleistocene strata, especially the limestones;

(3) topographic relief and elevation along the western margin of the basin during the first 3 m.y. was generally very low. Consequently, the extent of a landmassconnected meteoric wedge would also have been limited (Fig. 8B-D);

(4) compaction-driven fluids were derived not only from Pliocene-Pleistocene sediment but also from pre-Pliocene sediment, although the latter would become relatively minor as porosity and permeability decreased during compaction and diagenesis;

(5) fluids derived from older parts of the basin may have been driven along faults into deformed Pliocene strata, particularly fluids originating from deeper overpressured compartments (e.g., Darby et al. 2000). This would also apply to hydrocarbons migrating to structural or stratigraphic traps.

(6) uplift of the axial ranges over the last 2 m.y. resulted in a dramatic change to basin hydraulics, with farreaching topography-driven flow of meteoric fresh water (Fig. 8A).

The model can also account in a general way for each stage of calcite cementation in the Te Aute limestones: (1) precompaction calcite cements beneath emergent, faulted ridges (E1-2, W1); (2) burial and post-compaction calcite cements (E3, W2); (3) fracture-fill cements associated with compaction and deformation (W3); and (4) fracture-fill cements related to uplift and exposure of lithified limestone to near-surface meteoric conditions (E4-5, W4).

\section{CEMENTS E1 AND W1: MARINE CEMENTS}

The first indications of carbonate cementation are present as small, turbid, calcite crystals that coat the surfaces of skeletal fragments (Fig. 7A). Volumetrically, this cement stage is minor and is restricted to shallow-water facies above and below marine ravinement surfaces. Originally, the cements were most likely an intermediate- to high-Mg calcite, although now are low-Mg calcite (Caron 2002). A dissolution surface marks the upper boundary of the cements (Fig. 6).

Cements E1 and W1 are inferred to have been true marine cements (e.g., Nelson \& James 2000). As such they must have formed seaward of any meteoric wedge. However, the bounding dissolution surfaces indicate a fundamental change in water chemistry (e.g., Wigley \& Plummer 1976) that probably resulted from relative sea-level fall, subaerial exposure, and subsequent incursion of shallow, fresh water into the carbonate aquifer.

\section{SHALLOW METEORIC PROCESSES BENEATH EMERGENT ISLANDS: CEMENT E2}

\section{The freshwater lens}

Sparry calcite cements E2 (Fig. 7A,B), typically widespread throughout Kairakau Limestone, are interpreted to have precipitated from fresh water or dilute sea water before compaction. Meteoric fluids percolated through the entire succession presumably from a regionally developed exposure surface and for a prolonged period of time. Thus, it is inferred that the formation of the dissolution surface preceding cement E2 (Fig. 6) corresponds closely in time to the influx of fresh or brackish pore water after extended exposure of the limestone cap, thereby forming an emergent carbonate sand island (case 2 in Fig. 5). Precipitation of the pre-compaction low-Mg calcite spar cements must have begun soon after deposition because compaction of sediment and consequent expulsion of interstitial fluid begins very early in the history of sediment burial.

E2 cements differ markedly from more cryptic evidence of subaerial exposure recognised beneath the upper bounding surfaces of some Te Aute limestone sequences (e.g., within the Awapapa Limestone; Fig. 3). These discrete subaerial exposure surfaces, which are typically of limited geographic extent (i.e., a few hundreds of metres), record the short-lived emergence of small islands (case 1 in Fig. 5). Associated diagenetic fabrics include dissolution of metastable carbonate phases, percolation of non-marine sediments, and rare precipitation of tiny dogtooth, probably meteoric calcite crystals.

Fresh water that infiltrates the surface of an island accumulates as a groundwater lens, the extent of which is determined by the porosity and permeability of the surficial sediment and rock, and the hydraulic potential that is controlled primarily by relief on the water table. Freshwater lenses beneath islands are generally of limited aerial extent (Fig. 5) (Falkland 1991; Corbett et al 2000). Groundwater mapping on oceanic limestone-reef islands and atolls commonly demonstrates a freshwater lens a few metres deep and a freshwater/sea water mixing zone a few metres to tens of metres below the lens (e.g., Vacher \& Quinn 1997). Most of these examples are located in tropical seas and their sediments commonly consist of reef carbonates and cemented eolianites, unlike the cool-water settings that characterise the Te Aute carbonates. Nevertheless, water tables beneath these relatively low-relief islands commonly are $<1-2$ m elevation above sea level, and in general groundwater head values approach zero at the shoreline. Given sufficient hydraulic potential, groundwater may also discharge beyond the shoreline as submarine springs or diffuse seepage. In most cases, however, the extent and thickness of the groundwater 
lens is determined by the subaerial extent of the island (cf. cases 1 and 2 in Fig. 5).

The depth of the freshwater lens is controlled by three main factors: (1) the fresh groundwater hydraulic head distribution; (2) the net groundwater recharge (taking evaporation into account), and (3) the density difference between fresh and saline water. Approximation of the depth to the freshwater/sea water interface can be modelled using the Ghyben-Herzberg relation that is based on hydrostatic principles, wherein the weight of a column of fresh water measured from the water table to the interface $(h+z$ in Fig. 5) is balanced by the weight of a column of sea water extending from sea level to the interface ( $z$ in Fig. 5). The depth to the interface, and its geometry, can therefore be calculated from the function $z=40 h_{f}$, where $z=$ depth to the interface from sea level, and $h_{f}=$ the water table elevation above sea level. Thus, at a point where the water table is $1 \mathrm{~m}$ above sea level, the depth to the interface is $40 \mathrm{~m}$ below sea level. The Ghyben-Herzberg relation is an idealised solution because it assumes no mixing of the two fluids (fresh water and sea water), that the mixing zone itself is a plane, and that the plane intersects the water table at the shoreline. All three assumptions are demonstrably an oversimplification of the real world, but as many studies indicate (e.g., Vacher 1988; Underwood et al. 1992; Vacher \& Quinn 1997), the model is a reasonable first approximation of the extent of a coastal freshwater lens.

\section{Ghyben-Herzberg approximation of fresh water beneath the Te Aute islands}

Studied freshwater lenses beneath tropical carbonate and sandy barrier islands, and application of the Ghyben-Herzberg model, provide some constraints on the role of groundwater during emergence events, whether or not accompanied by cement precipitation.

(1) The areal extent of the freshwater lens would have been governed by the size of the islands, their relief, and groundwater recharge.

(2) Stratigraphic and petrographic evidence indicate that the Te Aute islands were capped by unconsolidated and noncemented skeletal sand and gravel. Thus, the topographic relief would have been very low and therefore the water table elevation would also have been very low.

(3) Even small changes in sea level potentially result in significant changes to the thickness and extent of the freshwater lens; for example, a $1 \mathrm{~m}$ reduction in the elevation of the water table (e.g., from a relative rise in sea level), results in a reduction of $40 \mathrm{~m}$ depth to the sea water interface.

(4) At any point in time, the potential zone of calcite cementation within a skeletal limestone body would have been restricted to the freshwater lens (including some of the mixing zone). Therefore, cementation beyond the confines of the lens would have required either falling sea level and a concomitant increase in island size, or migration of the freshwater lens forced by tectonic uplift (case 2 in Fig. 5). In either case, when cementation occurred, it is likely to have been diachronous. For the Kairakau Limestone, the early meteoric cements occupy a maximum amount of pore space in the southern outcrops, diminishing to the north. The northern limits of this cement phase therefore represent the approximate northern limit of the ancestral Kairakau island (Caron 2002).

\section{Constraints on groundwater flow rates beneath the Te Aute islands}

In islands like those envisaged for the Te Aute (Kairakau to Te Onepu) limestones, hydraulic potential and hydraulic gradients are low. Measured groundwater flow rates from modern sand islands commonly range from c. 0.1 to $0.5 \mathrm{~m} /$ day (e.g., Vacher \& Quinn 1997; Corbett et al. 2000). These rates are relatively low despite the generally high porosity and permeability; porosities of Te Aute skeletal sandstone and coquinas range from 10 to $40 \%$ (Harmsen 1989; Simpson \& Jarvis 1993), and therefore initial porosities were probably as high as $40-50 \%$.

Flow velocities are likely to have been greatest where hydraulic gradient is a maximum near the central parts of islands, decreasing towards the shoreline to values close to zero. Flow velocities will also be influenced by changes in sedimentary facies and prolonged periods of wet or dry weather. Assuming the measured velocities approximated those in the Te Aute islands, we estimate the travel time of a particle moving advectively across the island ranged from c. 8 to $12 \mathrm{yr} / \mathrm{km}$.

The volume of calcite cement precipitated in the freshwater lens will depend on the degree of saturation with respect to calcite and the number of pore volumes that flows through the system. The number of pore volumes will be greatest where flow rates are a maximum, decreasing towards the shoreline. Thus, the degree of low-Mg calcite cementation will also decrease towards the outer limits of the lens. For the Kairakau Limestone, this is probably reflected in the northwards decrease in E2 cements (Caron 2002).

The Pliocene-Pleistocene succession in the deeper parts of Hawke Bay (determined from seismic reflection) is c. $2000 \mathrm{~m}$ thick, giving an average sedimentation rate of 4-5 $\times 10^{-4} \mathrm{~m} / \mathrm{yr}$. A non-compacted, $50 \mathrm{~m}$ thick skeletal sand, for example, would take between 100000 and $125000 \mathrm{yr}$ to accumulate. This corresponds approximately to the time available to precipitate cement E2 within a freshwater lens, prior to burial and compaction to depths beyond the limits of the lens, and assuming some degree of uplift above sea level. The time period could be extended if the skeletal deposits were uplifted, such that sedimentation, and therefore burial rates, slowed.

\section{BURIAL-DOMINATED PROCESSES: CEMENTS E3 AND W2}

The conceptual models of Fig. 8 portray fluid flow paths and fluid sources on a basin-wide scale, and incorporate hydrostratigraphic, hydraulic, and geochemical terms that change in time and space as the basin evolves. The basis for these models derives from Galloway (1984) who defined three principal hydrogeologic regimes: (1) a meteoric regime driven primarily by (topographic) hydraulic potential along the basin margin; (2) a compactional regime where interstitial fluids are released as porosity is reduced; and (3) a deep thermobaric regime where dehydration reactions, particularly in clays, take place at elevated temperature and pressure. There is considerable overlap among the three regimes because, for example, compaction begins within a few to a few tens of metres of the sediment/water interface where meteoric 


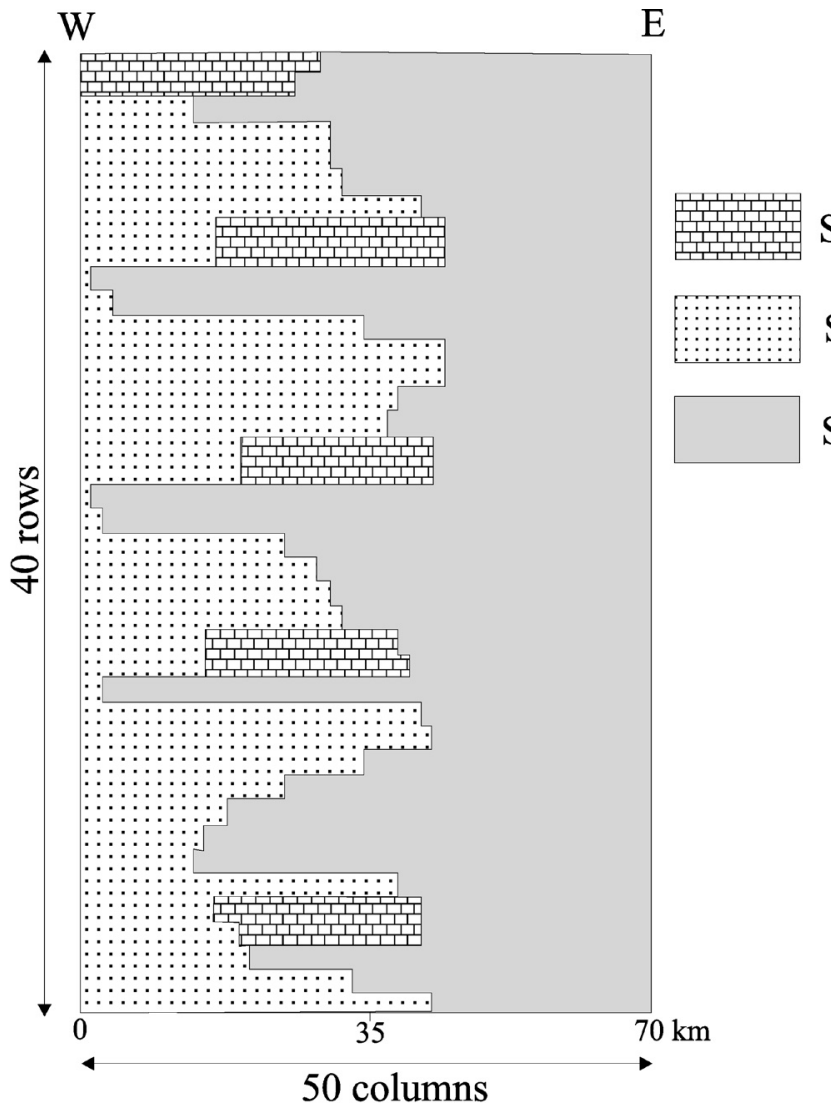

processes may predominate, and these meteoric processes can remain active to considerable depth in the basin depending on the hydraulic potential in the adjacent hinterland and the time available for flow.

For the case of the Te Aute limestones we need consider only the meteoric and compaction regimes, because the depth of burial was likely no more than c. $2 \mathrm{~km}$. Evidence from oil source rock studies and exploration wells in the East Coast Basin indicates that heat flow decreased markedly following the inception of late Oligocene subduction, and presently ranges from c. 30 to $40 \mathrm{~mW} / \mathrm{m}^{2}$ (Petrocorp Exploration Ltd 1995; Uruski \& Funnell 1995). Accordingly, burial temperatures were low throughout most of the forearc accretionary prism during the Pliocene-Pleistocene. As the conceptual model indicates (Fig. 8B-D), the topography of the western basin margin for the first $3.2 \mathrm{~m}$.y. following the beginning of the Pliocene consists of low-relief bedrock, with rapid uplift of the axial ranges taking place in the last 1.8-2.0 m.y. (Fig. 8A). The significance of the mountain uplift on meteoric input into the East Coast Basin must have been profound.

\section{Putting some numbers on burial fluid dynamics}

In marked contrast to cement E2, precipitation of the burial calcite cements involves fluids moving to much greater depths in the basin over significantly longer times, and where fluid chemistry is influenced by meteoric, compaction, and diagenetic processes. Quantification of the burial processes requires that we take into account changing porosity and permeability, and the fact that fluids will likely be derived from, and travel through, significant thicknesses of terrigenous mudrock and sandstone, in addition to the skeletal limestone units that on a basinal scale are very thin. The primary function

\section{Skeletal limestone aquifer}

\author{
Sandstone aquifer
}

Silty mudstone aquitard

Fig. 9 The stratigraphic architecture of the Pliocene-Pleistocene succession in southern Hawke's Bay is simplified to three main hydrostratigraphic units for use in the finite element simulations reproduced in Fig. 10. Hydraulic properties of the three units are listed in Table 1. The western half of the grid contains mostly coarse-grained clastics and the limestone bodies; the eastern half is dominated by mudrock. The five limestone units correspond approximately in thickness and lateral extent to the main periods of limestone accumulation during the Pliocene-Pleistocene. Faults have not been incorporated into the model grid as discussed in the text. The resulting thickness of the Te Aute succession in any column (i.e., any point across the basin) depends on the sedimentation rate that is varied across the model domain, to produce the basin geometry shown in Fig. 10. The water table is also varied across the top boundary of the model domain (see text for description).

of the current simulation is to simulate changes to the flow vectors (velocity and direction) and evolution of the meteoric wedge as sedimentation within the basin and topographic uplift of the basin margin progress.

The finite element code Rift2D (Person et al. 2000; Lampe \& Person 2002) was used to simulate fluid and heat transport within the upper $2 \mathrm{~km}$ of the East Coast Basin. Processes that result in fluid flow, including topographic drive, compaction, and variations in fluid density, can all be represented and coupled to conductive or convective heat flow. The model consists of a 2D, $70 \mathrm{~km}$ wide domain extending from the axial ranges in the west to offshore Hawke Bay. For reasons of scale, the model does not include changes within freshwater lenses beneath Kairakau-like islands.

\section{Finite element model input and boundary conditions}

The finite element grid consists of 50 element columns and 40 element rows. The thickness of the stratigraphic succession along any column is determined by the sedimentation rate, which is varied across the basin from a minimum $0.05 \times 10^{-4} \mathrm{~m} / \mathrm{yr}$ at the western basin margin to $6.25 \times 10^{-4} \mathrm{~m} / \mathrm{yr}$ in the east, allowing the basin to fill to a maximum of c. $2000 \mathrm{~m}$ in the first $3.2 \mathrm{~m}$.y. For the remaining $1.8 \mathrm{~m}$.y. the western half of the model is uplifted at $2.8 \times 10^{-4} \mathrm{~m} / \mathrm{yr}$ in the west, decreasing to zero in the centre of the model domain. Sedimentation in the eastern half of the domain over this time period continues at $1 \times 10^{-5} \mathrm{~m} / \mathrm{yr}$. The total simulation time from $5 \mathrm{Ma}$ to the Present was divided into 200 time periods of $25000 \mathrm{yr}$.

The stratigraphic architecture is predefined wherein the Pliocene-Pleistocene succession is simplified to three hydrostratigraphic units (Fig. 9), the properties of which 

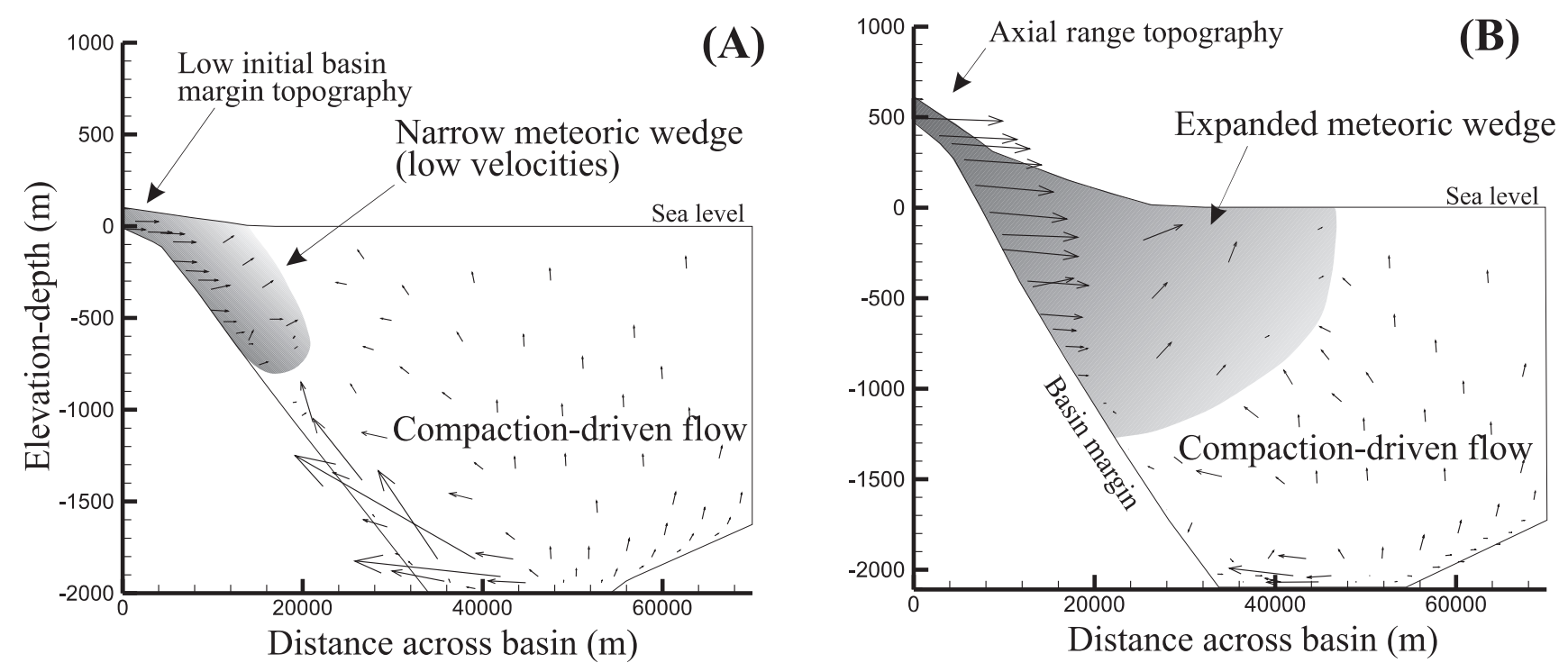

Fig. 10 A, Results of the pre-uplift simulation. Note the significant contribution to fluid flow derived from compaction (large vertical component of flow), and the limited depth and lateral extent of the meteoric wedge. The arrows indicate flow vectors (direction and velocity - see text for evaluation), and the base of arrows refers to specific elements in the finite element mesh. Flow velocities within the narrow meteoric wedge are low compared with compaction-driven velocities. B, Results of the post-uplift simulation. Uplift of the axial ranges has driven the meteoric wedge across the basin and to at least $1500 \mathrm{~m}$ depth. However, compaction-driven flow remains important, especially where it is focused through the more porous limestone bodies at depth. Note the significant difference in velocities in the expanded meteoric wedge compared with the velocities in the narrow wedge in (A).

are listed in Table 1. Unit thickness along any column in the model depends on the applied sedimentation rate. The resulting basin geometry is depicted in Fig. 10. Model sides and base are no-flow boundaries.

The upper model boundary represents the land/sea surface that has a maximum elevation of $100 \mathrm{~m}$ in the west decreasing to sea level about one-quarter of the distance across the model domain. This surface also acts as a proxy for the water table that controls topography-driven meteoric flow into the basin. The upper boundary conditions were changed after $3.2 \mathrm{~m}$.y. to allow uplift of the axial ranges over $1.8 \mathrm{~m}$.y.; the imposed water table at this time reached a maximum elevation of $500 \mathrm{~m}$, decreasing eastwards to zero at the shoreline.

Compilations of porosity-permeability data tend to indicate a $\log$-linear relationship of the form $\varphi=a_{1}+a_{2} \log (k)$, where $\varphi$ is porosity, $k$ is permeability $\left(\mathrm{m}^{2}\right)$, and $\mathrm{a}_{1}$ and $\mathrm{a}_{2}$ are dimensionless constants (e.g., Neuzil 1994). This relationship is used in Rift2D to account for changes in porosity during sedimentation. The choice of permeability or hydraulic conductivity values in groundwater-fluid flow modelling is important because most models are highly sensitive to variations in these parameters (Freeze \& Cherry 1979; Belitz \& Bredehoeft 1988; Neuzil 1994). The values listed in Table 1 represent average initial values for the three lithologies used here. Porosity-permeability values for the limestones and sandstones correspond with average values documented in outcrop and well data in the Te Aute Group (Harmsen 1989; Simpson \& Jarvis 1993; Beu 1995; Nelson et al. 2003). In the absence of measured permeabilities for the mudrocks, a generic value was selected (Table 1) (Neuzil 1994; Person et al. 2000).

Heat flow values determined from exploration wells in the basin presently range between 30 and $40 \mathrm{~mW} / \mathrm{m}^{2}$ (Petrocorp Exploration Ltd 1995). For this simulation, a value of $35 \mathrm{~mW} / \mathrm{m}^{2}$ was used across the model domain. Surface temperatures were set to $10^{\circ} \mathrm{C}$. Heat flow and surface temperature values were held constant during the simulation. Matrix and fluid thermal conductivity values are based on averages from other basin-fluid flow analyses, including similar-aged rocks in Taranaki Basin (e.g., Person \& Garven 1992; Funnell et al. 1996; Lampe \& Person 2002).

Faults are not incorporated into the model. As the example seismic profiles indicate (Fig. 4), faulting is an integral component of the East Coast Basin, generated primarily by accretionary prism tectonics. The fault style in the basin is dominated by east-verging thrusts (Pettinga 1982; Lewis \& Pettinga 1993; Field et al. 1997) that are likely to have

Table 1 Material properties of hydrostratigraphic units forming the Pliocene-Pleistocene strata, and used in the Rift2D simulation.

\begin{tabular}{|c|c|c|c|}
\hline Physical property & Skeletal limestone & Marine sandstone & Marine mudstone \\
\hline Log permeability $\left(\mathrm{m}^{2}\right)$ & -11.5 & -13 & -14.5 \\
\hline Initial porosity & 0.6 & 0.4 & 0.5 \\
\hline Vertical permeability anisotropy & 10 & 5 & 10 \\
\hline Fluid thermal conductivity $\left(\mathrm{W} / \mathrm{m}^{\circ} \mathrm{C}\right)$ & 0.58 & 0.58 & 0.58 \\
\hline Solid thermal conductivity $\left(\mathrm{W} / \mathrm{m}^{\circ} \mathrm{C}\right)$ & 2.5 & 2.5 & 1.45 \\
\hline
\end{tabular}


focused flow or acted as barriers to flow (Darby et al. 2000). Active faulting may also have resulted in sealing or breaching of overpressured compartments within the basin (Darby et al. 2000; Davies et al. 2000). Depending on proximity to the basin margin, faults also are likely to have influenced the lateral extent of the meteoric wedge, particularly where permeable units are juxtaposed against aquitards. The Rift2D code can incorporate active rift-style, extensional faulting in a simulation but not thrust faulting. Furthermore, the fluid pressure/stress regime associated with thrust faulting is fundamentally different to that in extensional regimes. Therefore, if the above conditions apply, the modelled flow extents, particularly the lateral extent of the meteoric wedge, are likely to be a maximum.

\section{Modelled flow across the basin}

Fluid velocity profiles generated at specified time periods clearly illustrate the two main sources of fluid and their driving mechanisms. In Fig. 10A (from 5.0 to $3.2 \mathrm{Ma}$ ), flow in the developing basin is dominated by compaction-drive where flow is directed upwards and towards the basin margins. A meteoric wedge of limited lateral extent and depth does exist along the western basin margin (flow vectors directed out from the margin). However, the depth of topography-driven meteoric flow is much less than $1000 \mathrm{~m}$ in the simulation, and at these depths velocities are slow. Meteoric influences probably did not extend laterally much beyond the limits of the exposed landmass.

Therefore, it is proposed that the paucity or absence of pre-compaction meteoric cements within the Titiokura and Te Waka Limestones (Fig. 2, 6) indicate either that the western shelf was never exposed for a prolonged period of time following deposition, or that the adjacent landmass was not elevated enough to allow basinward transfer of potentially cementing fluids.

Uplift of the axial ranges over the last c. 2 m.y. had a profound effect on flow dynamics in the still-subsiding basin. This is reflected in the greatly increased flow velocities and extent of the meteoric wedge that in this simulation is driven to almost $1500 \mathrm{~m}$ depth and up to $40 \mathrm{~km}$ beyond the western uplift (Fig. 10B). Compaction-driven flow also remains significant at $2 \mathrm{~km}$ burial depth.

As expected, flow velocities are greatest in the porous sandy-textured deposits along the western half of the basin. Within the limestone units, flow ranges from 0.03 to $0.05 \mathrm{~m} /$ day near the base of the succession (c. $2 \mathrm{~km}$ burial), whereas velocities in the mudstone commonly are three orders of magnitude lower $\left(5.5 \times 10^{-5} \mathrm{~m} /\right.$ day; Fig. 10A,B $)$. Note, however, that model velocities in the compacted limestones are at least an order of magnitude less than those determined for the non-compacted skeletal sands. For example, the time for fluids to traverse a $2 \mathrm{~km}$ length of limestone (as in the Kairakau freshwater lens model) would take almost $200 \mathrm{yr}$, compared to 16-27 yr for flow at near-surface conditions. At these depths, flow over an equivalent distance through the compacted muddy lithologies would take up to $100000 \mathrm{yr}$.

\section{Model calibration}

Although there are few records of formation water composition at depth in East Coast Basin exploration wells (Fig. 2), those that do exist accord reasonably well with model results: Ongaonga-1 well intersected porous, freshwater-filled coquina at c. $1300 \mathrm{~m}$ depth (Leslie 1971a); Mason Ridge-1 well showed fresh water to $580 \mathrm{~m}$ depth, becoming brackish at $780 \mathrm{~m}$ (Leslie 1971b); and Takapua-1 well contained fresh water to $840 \mathrm{~m}$ becoming brackish (c. $8000 \mathrm{ppm}$ chloride) at $1000 \mathrm{~m}$ (Leslie 1971c). An interesting comparison can be made with the Whangaehu-1 and Parikino-1 wells in onshore Wanganui Basin, that contain broadly similar Pliocene-Pleistocene stratigraphy and are located a few tens of kilometres west of the axial ranges. Relatively fresh water ( $<4000$ ppm chloride) extends to $2500 \mathrm{~m}$ in the Whangaehu1 well (Brown 1996), and is intersected in Tangahoe Group sands between 1343 and $1840 \mathrm{~m}$ depth (St John 1964). Clearly, uplift of the axial ranges had a profound effect on meteoric fluid drive in both basins (Ricketts 1999).

\section{Interpretation of precipitation conditions for cements E3 and W2}

The occurrence of the thick post-compaction cement W2 suggests the existence of extended compaction-driven paleohydrological flow that passed through the Titiokura and Te Waka aquifers. The burial fluids may have originated partly from meteoric fluids sourced in an elevated landmass to the west, that became progressively mixed with basinderived modified sea water and buried below the influence of well-oxygenated waters, therein allowing precipitation of ferroan-rich calcite crystals (Fig. 7D) (Caron 2002).

For the duration of much of the forearc basin, the eastern setting was disconnected from the western ranges and remained isolated from any significant proximal landmass until uplift eventually led to emergence of the Coastal Highlands (Fig. 8C) (Beu 1995). Cement E3 is moderately to poorly ferroan (Fig. 6). Precipitation of cement E3 is interpreted to originate from compaction-driven flows of limited velocities, but probably higher in the lower units decreasing up-section (Fig. 8B,C), as suggested by the thinning-upward trend of cements (Caron 2002). Moderate to low ferroan content of cement E3, in marked contrast with that of cement W2, further supports isolation from a terrigenous source.

\section{EARLY UPLIFT AND FRACTURING: CEMENTS E4 AND W3}

The early stages of uplift of a now-lithified limestone resulted in fracture porosity that became the site for early uplift-related calcite cements. Flow of modified formation fluids at depth would have been focused along the fractures, although some diffuse flow through the remaining intergranular pore spaces likely continued. Most of the fracturing would have taken place during faulting or uplift.

Sourcing of the fluids responsible for this stage of cementation is uncertain, but is likely to be bipolar to account for the observed differences in attributes between cements E4 and W3 (Fig. 6). Caron (2002) proposed that E4 cements formed from oxidising meteoric groundwaters that entered the previously sealed carbonate system while the units were being tectonically exhumed. In Nukumaruan times, emergent growth fold structures could have constituted satisfactory recharge areas for cement E4. The cements are characterised by low $\delta^{13} \mathrm{C}$ values, interpreted by Caron (2002) as requiring an allochthonous source of carbon. For meteoric carbon input this would require uplift of the rocks, probably to within a few $100 \mathrm{~m}$ of the surface. An alternative source of carbon might have been older, deeper fluids, especially those having contact 
with hydrocarbons (Harmsen 1989) that migrated to shallow depths along fractures and faults.

In the western area, if cementation took place at depths approaching $2000 \mathrm{~m}$ then it is unlikely that fluids within the meteoric wedge played a major role, especially if cementation occurred before uplift of the axial ranges. This constraint is clearly demonstrated by the extent of the meteoric wedge in the finite element model (Fig. 10A). Therefore, it is suggested that the conformable succession of cementing stages within cement W3, with decreasing amounts of ferroan content porewards (Fig. 7D), records the progressive uplift and progressive dilution of a buried cementing aquifer by surficial oxidised waters.

\section{LATE UPLIFT AND EXPOSURE: CEMENTS E5 AND W4}

The latest phase of cementation in the Te Aute limestones took place along a younger set of fractures that crosscuts all earlier cement stages. Cement E5 includes bright luminescent and mainly non-luminescent zones that Caron (2002) interprets as having precipitated from shallow meteoric waters in Pleistocene times when most of the forearc basin was becoming exposed (Fig. 6). In the western area, regional uplift associated with the axial ranges must have moved the limestone-bearing strata to a position well within the meteoric wedge, thereby allowing precipitation of cement W4 from well-oxidised and proximally sourced meteoric waters.

\section{CONCLUSIONS}

Pliocene cool-water, bioclastic limestones in East Coast Basin formed in a tectonically active accretionary forearc prism above the west-dipping Hikurangi Subduction Zone. On the eastern margin of the forearc basin seaway, limestones in particular accumulated in shallow, high energy marine environments, about growing anticlines that were located at the termination of deep-seated thrust faults. For each of the Pliocene limestone units in this setting, five stages of carbonate cementation, labelled E1-E5, are recognised, based on cement sequence-stratigraphic concepts (Caron 2002) that took place on the seafloor, during exposure of the limestones before burial, during burial, uplift, and deformation. On the western margin, prolonged subaerial exposure of the limestones before burial did not occur, and as a result a maximum of only four cement stages are present, labelled W1-W4.

Two principal fluid types are identified-topographydriven meteoric fluids, and compaction-driven fluids. We have developed conceptual and quantitative models that attempt to relate the physical characteristics of fluid flow to the cement paragenesis.

The relationship between fluid flow and each cement is summarised as follows:

Cements $E 1$ and $W 1-\mathrm{Mg}$ calcite marine cements formed in shallow marine environments that were remote from meteoric freshwater influence.

Cement E2 - pre-compaction, low-Mg calcite spar formed in shallow freshwater lenses beneath tectonically uplifted "islands". The depth of fresh water probably did not exceed 40-80 m. Based on modern analogues, freshwater flow rates were probably in the order of $0.0 .1-0.5 \mathrm{~m} /$ day, depending on the local water table elevation and gradient.

Cements E3 and W2 - post-compaction, low-Mg calcite spar precipitated primarily from compaction-driven formation fluids (modified sea water or buried mixed marine-meteoric fluid). Finite element modelling suggests that prior to uplift of the axial ranges (before c. $2 \mathrm{Ma}$ ), the meteoric wedge derived from the low-relief hinterland did not extend far beyond the (western) basin margin, and perhaps only to a few $100 \mathrm{~m}$ depth in the basin. The dynamics of meteoric flow changed dramatically during subsequent uplift of the axial ranges, such that the modelled lateral extent of the meteoric wedge is at least $40 \mathrm{~km}$ across the basin, and the depth up to $1500 \mathrm{~m}$ or more. Flow velocities in limestones at $2000 \mathrm{~m}$ burial depth are an order of magnitude lower than at the surface (significant porosity is preserved at this depth), and in mudrocks is reduced to c. $10^{-5} \mathrm{~m} /$ day.

In the eastern sector of the study area, strata remained isolated from the main fluid flow pathways derived from the west. As a result, cement E3 is typically thin and moderately ferroan due also to isolation from a proximal terrigenous source. In the western strata, burial cement W2 is thick and ferroan rich. It likely precipitated from fluids modified by burial. Either these fluids were partly derived from the adjacent landmass and later were cut off from their recharge area and mixed with sea water, or modified sea water was the main cementing fluid away from meteoric-sourced waters. The former hypothesis is supported by the high ferroan content of W2 cements, indicative of continent-derived input of iron.

Cements E4, E5, W3, and W-these are early and late upliftrelated calcite cements, associated with fracturing. Cements E4 and E5 formed in a shallow meteoric aquifer. Their low $\delta^{13} \mathrm{C}$ values may have resulted from allochthonous soilderived meteoric carbon or possibly from hydrocarbons deeper in the basin that flowed through the fracture zones. Cement W3 displays a conformable succession of cementing stages with decreasing ferroan contents porewards, indicative of progressive dilution of the buried aquifer by oxidised fluids during uplift. Cement W4 precipitated when strata were eventually uplifted into a region of shallow meteoric diagenesis.

\section{ACKNOWLEDGMENTS}

We thank particularly Peter Kamp, Arne Pallentin, Alan Beu, and Dave Francis for many discussions about the stratigraphy and diagenesis of the Te Aute limestones. Funding support for this study came from within Marsden Contract UOW801 (Royal Society of New Zealand) to the University of Waikato. Mark Person, University of Minnesota, is thanked for providing the Rift2D code. The constructive criticisms and comments of reviewers Julie Rowland and David Darby are gratefully acknowledged.

\section{REFERENCES}

Bachu, S. 1995: Synthesis and model of formation-water flow, Alberta Basin, Canada. American Association of Petroleum Geologists Bulletin 79: 1159-1178.

Ballance, P. F. 1993: The New Zealand Neogene forearc basins. In: Ballance, P. F. ed. Sedimentary basins of the world, 2. South Pacific sedimentary basins. Amsterdam, Elsevier. Pp. 177-193. 
Belitz, K.; Bredehoeft, J. D. 1988: Hydrodynamics of Denver Basin: explanation of subnormal fluid pressures. American Association of Petroleum Geologists Bulletin 72: 1334 1359.

Bethke, C. M. 1989: Modelling subsurface flow in sedimentary basins. Geology 78: 129-154.

Beu, A. G. 1995: Pliocene limestones and their scallopslithostratigraphy, pectinid biostratigraphy and paleogeography of eastern North Island late Neogene limestone. Institute of Geological \& Nuclear Sciences Monograph 10. Lower Hutt, New Zealand, Institute of Geological \& Nuclear Sciences Ltd. 243 p.

Bjorlykke, K. 1993: Fluid flow in sedimentary basins. Sedimentary Geology 86: 137-158.

Bjorlykke, K. 1994: Fluid-flow processes and diagenesis in sedimentary basins. In: Parnell, J. ed. Geofluids: origin, migration and evolution of fluids in sedimentary basins. Geological Society Special Publication 78: 127-140.

Brown, I. R. \& Associates 1996: Whangaehu-1 well completion report, PPL 38708. Unpublished open-file petroleum report 2195. Wellington, Ministry of Commerce.

Caron, V. 2002: Petrogenesis of Pliocene limestones in southern Hawke's Bay, New Zealand: a contribution to unravelling the sequence stratigraphy and diagenetic pathways of cool-water shelf carbonate facies. Unpublished $\mathrm{PhD}$ thesis, University of Waikato, Hamilton, New Zealand.

Caron V.; Nelson, C. S. 2001: Cathodoluminescence sequences in the Early Pliocene cool-water Kairakau Limestone, Hawke's Bay, New Zealand. In: Cathodoluminescence in geosciences: new insights from CL in combination with other techniques. CL 2001, 06 to 08 September 2001, Freiberg, Germany, abstracts. Freiberg, University of Mining and Technology. $18 \mathrm{p}$.

Caron, V.; Nelson, C. S. 2003: Developing concepts of highresolution diagenetic stratigraphy for Pliocene cool-water limestones in New Zealand, and their sequence stratigraphy. Carbonate and Evaporites 18: 63-85.

Caron, V.; Nelson, C. S.; Kamp, P. J. J. 2004: Contrasting carbonate depositional systems for Pliocene cool-water limestones cropping out in central Hawke's Bay, New Zealand. New Zealand Journal of Geology and Geophysics 47: 697-717 (this issue).

Corbett, D. R.; Dillon, K; Burnett, W. 2000: Tracing groundwater flow on a barrier island in the north-east Gulf of Mexico. Estuarine, Coastal and Shelf Science 51: 227-242.

Darby, D.; Funnell, R.; Uruski, C. I.; Field, B. D. 2000: Patterns of fluid flow in the East Coast Basin. In: 2000 New Zealand Petroleum Conference Proceedings. Petroleum and Geothermal Unit, Ministry of Commerce. Pp. 355-364.

Davies, E. J.; Frederick, J. B.; Leaske, W. L.; Williams, T. J. 2000: East coast drilling results. In: 2000 New Zealand Petroleum Conference Proceedings. Petroleum and Geothermal Unit, Ministry of Commerce. Pp. 84-93.

de Caen, R. F. B.; Darley, J. H. 1968: An examination of Wanganui carbonates, Hawke's Bay, North Island, New Zealand. BP Shell Aquitaine and Todd Petroleum Development Ltd Report TN37. Lower Hutt, New Zealand, Institute of Geological \& Nuclear Sciences unpublished open-file report 382.

de Caen, R. F. B.; Darley, J. H. 1969: An examination of Wanganui carbonates, Dannevirke area, North Island, New Zealand. BP Shell Aquitaine and Todd Petroleum Development Ltd Report TN39. Lower Hutt, New Zealand, Institute of Geological \& Nuclear Sciences unpublished open-file report 384

Dickson, J. A. D. 1965: A modified staining technique for carbonates in thin-section. Nature 205: 587.
Falkland, A. ed. 1991: Hydrology and water resources of small islands: a practical guide. UNESCO International Hydrological Programme, IHP-III, Project 4.6.

Field, B. D.; Uruski, C. I. and others 1997: Cretaceous-Cenozoic geology and petroleum systems of the East Coast region, New Zealand. Institute of Geological \& Nuclear Sciences Monograph 19. Lower Hutt, New Zealand, Institute of Geological \& Nuclear Sciences Ltd. 301 p.

Freeze, R. A.; Cherry, J. A. 1979: Groundwater. New Jersey, PrenticeHall. 604 p.

Funnell, R.; Chapman, D.; Allis, R.; Armstrong, P. 1996: Thermal state of the Taranaki Basin, New Zealand. Journal of Geophysical Research 101: 25197-25215.

Galloway, W. E. 1984: Hydrogeologic regimes of sandstone diagenesis. In: McDonald, D. A.; Surdam, R. C. ed. Clastic diagenesis. American Association of Petroleum Geologists Memoir 37: 3-13.

Hanor, J. S. 1994: Physical and chemical controls on the composition of waters in sedimentary basins. Marine and Petroleum Geology 11: 31-45.

Harmsen, F. J. 1985: Lithostratigraphy of Pliocene strata, central and southern Hawke's Bay, New Zealand. New Zealand Journal of Geology and Geophysics 28: 413-433.

Harmsen, F. J. 1989: Te Aute Group limestones: a potential reservoir rock in the East Coast Basin, New Zealand. In: New Zealand Oil Exploration Conference Proceedings. Wellington, Petroleum and Geothermal Unit, Ministry of Commerce. Pp. 181-190.

Harrison, W. J. 1989: Modeling fluid/rock interactions in sedimentary basins. In: Cross, T. A. ed. Quantitative dynamic stratigraphy. New Jersey, Prentice-Hall. Pp. 195-231.

Haywick, D. W.; Lowe, D. A.; Beu, A. G.; Henderson, R. A.; Carter, R. M. 1991: Pliocene-Pleistocene (Nukumaruan) lithostratigraphy of the Tangoio block, and origin of sedimentary cyclicity, central Hawke's Bay, New Zealand. New Zealand Journal of Geology and Geophysics 34: 213-225.

Hutcheon, I. 1990: Aspects of the diagenesis of coarse-grained siliciclastic rocks. In: McIlreath, I. A.; Morrow, D. W. ed. Diagenesis. Geoscience Canada Reprint Series 4: 165-176.

Kamp, P. J. J.; Nelson, C. S. 1987: Tectonic and sea-level controls on non-tropical Neogene limestones in New Zealand. Geology 15: 610-613.

Kamp, P. J. J.; Harmsen, F. J.; Nelson, C. S.; Boyle, S. F. 1988: Barnacle-dominated limestone with giant cross-beds in a non-tropical, tide-swept, Pliocene forearc seaway, Hawkes Bay, New Zealand. Sedimentary Geology 60: 173-195.

Lampe, C.; Person, M. 2002: Advective cooling within sedimentary rift basins - applications to the Upper Rhinegraben (Germany). Marine and Petroleum Geology 19: 361-375.

Leslie, W. C. 1971a: Ongaonga-1, Beaver Exploration NZ Ltd. Unpublished open-file petroleum report 271. Wellington, Ministry of Commerce.

Leslie, W. C. 1971b: Mason Ridge-1, PPL479, Beaver Exploration NZ Ltd. Unpublished open-file petroleum report 272. Wellington, Ministry of Commerce.

Leslie, W. C. 1971c: Takapau-1, Beaver Exploration NZ Ltd. Unpublished open-file petroleum report 273. Wellington, Ministry of Commerce.

Lewis, K. B.; Pettinga, J. R. 1993: The emerging imbricate frontal wedge of the Hikurangi Margin. In: Ballance, P. F. ed. Sedimentary basins of the world, 2. South Pacific sedimentary basins. Amsterdam, Elsevier. Pp. 225-250.

Nelson, C. S.; James, N. P. 2000: Marine cements in mid-Tertiary cool-water shelf limestones of New Zealand and southern Australia. Sedimentology 47: 609-629. 
Nelson, C. S.; Winefield, P. R.; Hood, S. D.; Caron, V.; Pallentin, A.; Kamp, P. J. J. 2003: Pliocene Te Aute limestones, New Zealand: expanding concepts for cool-water shelf carbonates. New Zealand Journal of Geology and Geophysics 46: 407-424.

Neuzil, C. E. 1994: How permeable are clays and shales? Water Resources Research 30: 145-150.

Person, M.; Garven, G. 1992: Hydrologic constraints on petroleum generation within continental rift basins; theory and application to the Rhine Graben. Association of Petroleum Geologists Bulletin 76: 468-488.

Person, M.; Neuzil, C.; Hseih, P.; Mailloux, B.; Bekele, E.; Swenson, J.; Eadington, P. 2000: Rift2D: a finite element model for simulating two-dimensional ground water flow, heat, solutemass transport, and petroleum generation within evolving sedimentary basins (user guide). Minneapolis, University of Minnesota, Department of Geology and Geophysics. $210 \mathrm{p}$.

Petrocorp Exploration Ltd 1995: BasinMod modelling in PPL 38316 , Hawke's Bay, East Coast Basin, New Zealand. Unpublished open-file petroleum report 2146. Wellington, Ministry of Commerce.

Pettinga, J. R. 1982: Upper Cenozoic structural history, coastal southern Hawkes Bay, New Zealand. New Zealand Journal of Geology and Geophysics 25: 149-191.

Ricketts, B. D. 1999: Evolution of the Wanganui Basin plumbing system: preliminary models of regional groundwater and fluid flow. Geological Society of New Zealand Miscellaneous Publication 107A: 138
Ricketts, B. D.; Nelson, C. S.; Caron, V.; Pallentin, A. 2001: Pliocene to Recent deformation of the East Coast forearc basin revealed by seismic sequences beneath Hawke Bay, New Zealand. Geological Society of New Zealand Miscellaneous Publication 110A: 133.

Simpson, J.; Jarvis, J. 1993: Technical review of the East Coast Basin. Petroleum Report 1972, Wellington, Ministry of Commerce.

St John, D. H. 1964: Parikino-1 exploration well resume. Shell \& BP Todd Oil Services. Unpublished open-file petroleum report 452. Wellington, Ministry of Commerce.

Underwood, M. R.; Peterson, F. L.; Voss, C. I. 1992: Groundwater lens dynamics of atoll islands. Water Resource Research 28: 2889-2902.

Uruski, C. I.; Funnell, R. H. 1995: Heat flow and maturation along seismic line IAE1-8, PPL 38323, East Coast Basin, North Island, New Zealand. Unpublished open-file petroleum report 2210. Wellington, Ministry of Commerce.

Vacher, H. L. 1988: Dupuit-Ghyben-Herzberg analysis of stripisland lenses. Geological Society of America Bulletin 100: $580-591$.

Vacher, H. L.; Quinn, T. M. ed. 1997: Geology and hydrogeology of carbonate islands. Developments in Sedimentology 54. Amsterdam, Elsevier. 948 p.

Wigley, T. M. L.; Plummer, L. N. 1976: Mixing of carbonate waters. Geochimica et Cosmochimica Acta 40: 989-995. 